\title{
Food Ordering Application with Scheduling Feature Based on Mobile Web (Pasti Makan)
}

\author{
I Gusti Bagus JB Surya Bhuana \\ Departement of Information \\ Technology \\ Faculty of Engineering, \\ Udayana University \\ Badung, Bali, Indonesia
}

\author{
I Nyoman Piarsa \\ Departement of Information \\ Technology \\ Faculty of Engineering, \\ Udayana University \\ Badung, Bali, Indonesia
}

\author{
I Made Sukarsa \\ Departement of Information \\ Technology \\ Faculty of Engineering, \\ Udayana University \\ Badung, Bali, Indonesia
}

\begin{abstract}
Over time, the development of information technology has produced a variety of applications that provide convenience for humans, such as the application of food delivery. This application was designed from a background of productive individual conditions who have less time to buy food. Gofood is one of the features in the Gojek application that realizes the concept of food delivery. However, this feature does not give consumers the freedom to determine the food arrival time. Consumers did self estimation about the time when placing an order to obtain the arrival time as desired. Based on these weaknesses, Pasti Makan application was designed. This application provides scheduling features so that food ordering can be done at various times and the order will still arrive in accordance with the time specified by the consumer. This research focuses on solving the problem of the arrival time in order delivery. The purpose of this study is that buyers get their orders within the allotted time. This system made by using the PHP programming language and Javascript.
\end{abstract}

Keywords: e-commerce; food delivery; ordering; scheduling; website

\section{INTRODUCTION}

In the era of globalization, technological progress has developed very rapidly [1]. The development of technology, causes information can be received easily and quickly [2]. It cannot be denied that information technology has become one of human's main needs [3]. One of the developments in information technology is the internet [4].

The use of internet in business has developing, from electronic information exchange to business strategy applications, such as marketing, sales, and customer service [5]. The collaboration of internet and digital media, is able to create applications that make it easy for the community in their activities, such as the application in ordering food. Some companies have realized that the application of food ordering is a potential idea that can bring profits.

One example of food ordering application is Gojek. Gojek is one of the providers of online transportation services through applications available on the Android and iOS operating systems [6]. The application offers ordering and delivering food directly to the buyer. However, Gojek drivers do not always deliver their orders quickly and become a problem for Gojek users who have a tight time. The problem of delivering food orders which is fulfill of consumers wishes, is a problem for consumers who have a limit time.

Based on these problems, researchers designed a food ordering application in the form of a website application that provide guaranteed delivery of food orders according to the desired time. This solution is expected to solve the problem of time that is often experienced by consumers who have a limit time. In addition to solving the problem, this application is expected to open new jobs for the community, especially for mothers who want to sell food without having to open a shop.

\section{METHODOLOGY}

The research method used in compiling a service system called "Food Order Application System with Mobile Website Based Scheduling Features (Pasti Makan)" is waterfall model system design methodology.

\subsection{Application Overview}

General image of the system from making the Pasti Makan Website Application. The system of mobile website application Pasti Makan uses HTML and PHP languages as the basis for making the system.

Pasti Makan Application Website is an ordering system that can be done online by anyone and at any time using a scheduling system. Figure 1 is an illustration about Application Website Pasti Makan system.

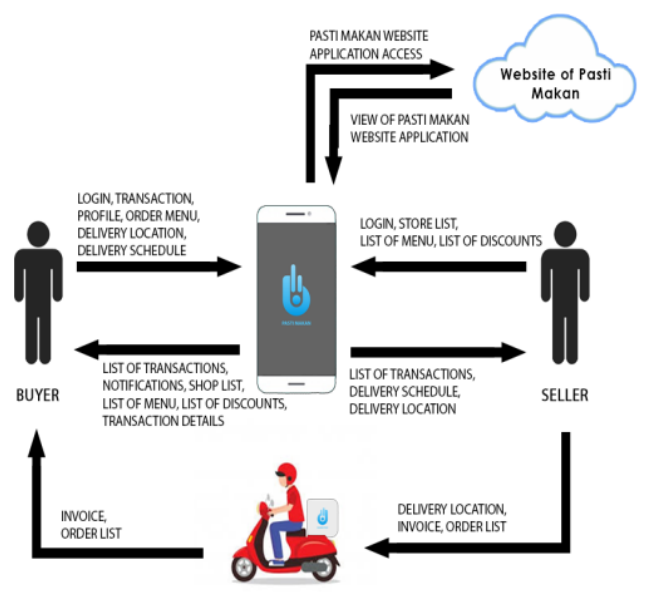

Figure 1. Application Overview

Figure 1 describing that the buyer makes transactions on the system with the desired order menu. After that, the buyer provides information about buyer data, location and schedule to the system. The system begin provides information to store users to process orders that have been ordered. Orders are 
then delivered to the buyer by the store according to the buyer's specified schedule.

\subsection{Data Flow Diagram}

Data Flow Diagrams of Pasti Makan Application Website is describe as Figure 2.

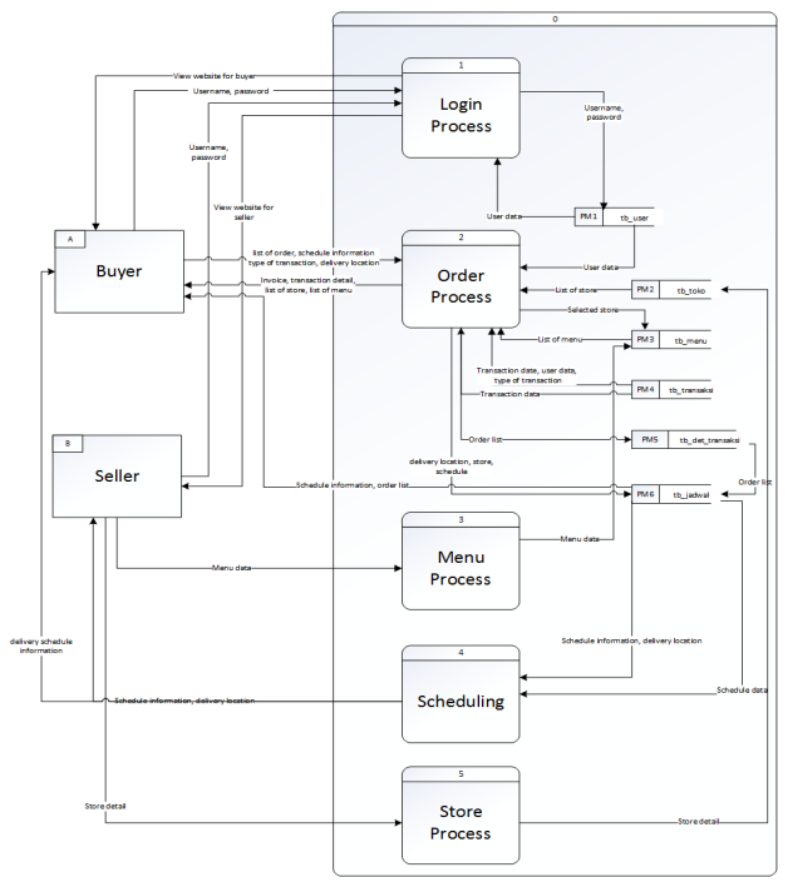

Figure 2. Data Flow Diagram

From Figure 2, there are 6 main processes, namely the login process, the ordering process, the menu process, the store process and the scheduling process. The login process is the process when the buyer or seller user enters the system by entering a username and password. The ordering process is the process when the buyer makes an order through the Pasti Makan system. When ordering process, buyer needs to choose the store and menu to be ordered while entering the delivery location, delivery date and delivery time. The menu process is the seller's process for managing menu data from owned stores, such as adding new menus, changing menus and removing menus. The store process is the seller's process for managing the store, such as deleting a store, changing store information and adding a new store. The scheduling process is the process of the system to display the list of interagency schedules to sellers through transaction data sorted by the closest interagency schedule.

\subsection{Entity Relationship Diagram}

Entity Relationship Diagram of Pasti Makan can be seen from Figure 3.

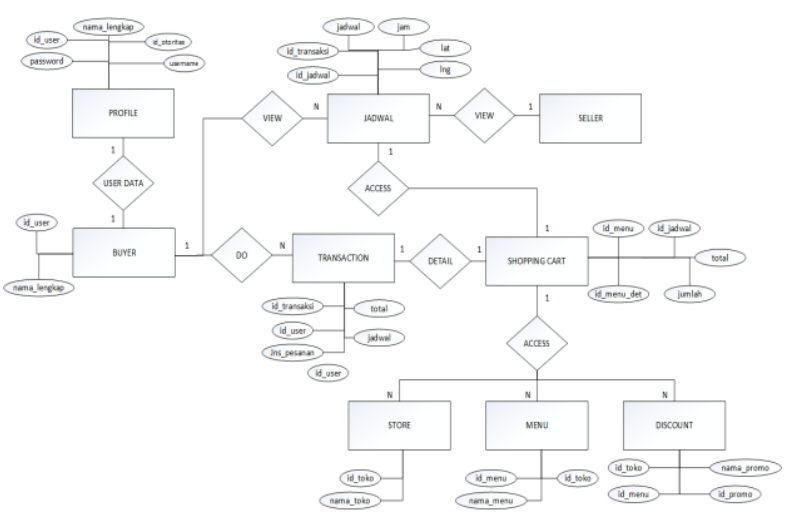

Figure 3. Entity Relationship Diagram

Figure 3 explains how the relationship between entities, processes and databases. This application has three entities namely buyer, seller and admin. Buyers have a relationship between admin and seller. The buyer places an order with the seller. While the seller delivers the buyer's order according to the specified schedule.

\section{LITERATURE REVIEW}

Literature review is material that is used as a reference in making research. The following references are to an explanation of Cloud Computing, Google Maps API, taking order, PHP, Javascript, and scheduling.

\subsection{Cloud Computing}

Cloud Computing is a combination of using computer technology and development based on Internet [7]. According to Satya Saputra (2017), cloud computing is a service model for sharing configurable computing resources (for example, networks, servers, storage, applications and services) that can be quickly run over the internet. One of the advantages of cloud technology is allows users to store data centrally on one server based on services provided by cloud computing service providers [8]. Cloud computing services have 3 service models that can be used as needed, 3 services include IaaS, $\mathrm{PaaS}$ and SaaS [9].

\subsection{Google Maps API}

Google Maps is software on the Internet that contains maps of an area or location [10]. Google Maps can be displayed on the web or external applications by using the Google Maps API [11]. The Google Maps application can be displayed on a particular web or application that requires an API key as a unique code generated by Google for a particular website or application so that the Google Maps server can recognize developers who use the Google Maps API service [11].

\subsection{Taking Order}

Taking Order in a restaurant is the activity of receiving and recording guest orders. In this case, food and drinks will be forwarded to the relevant section, including the kitchen, bar, and cashier [12].

Taking Order includes several activities, such as:

1. Displays accurate information about all available foods and drinks in the menu list.

2. Note the menu ordered, the number ordered, the name of the customer and others.

3. Confirm the order to the customer.

4. Forward the order to the related section. 


\subsection{Scheduling}

Scheduling is a planning activity to determine when and where each operation as part of the overall work must be done on limited resources, as well as allocating resources at a certain time by taking into account the capacity of existing resources.

The main function of production scheduling is to make the production process run smoothly according to the planned time, so that it works at full capacity with minimal costs and the desired quantity of products can be produced on time [13]

\subsection{PHP (Hypertext Prepocessor)}

PHP is a scripting language that can be embedded or inserted into HTML. PHP is widely used for dynamic website programming [14]. PHP is referred to as HTML embedded server side scripting, because all scripts in PHP are run on the server side. PHP scripts integrated with HTML [15]. PHP code can be built on a web page system by building it with pure PHP language, combined with HTML code, or combined with various template engines and web frameworks. [16].

PHP is used and run on a web page to process the contents of the website seen by visitors of the website [17].

\subsection{Javascript}

Javascript is a scripting language, which is a set of instructions commands used to control some parts of the operating system [18]. Javascript is developed to be able to run on a web browser or client side [18].

Javascript makes the server load lighter and web pages will respond much faster, even on the lowest internet connections [19]. JavaScript is a category of language that is case sensitive which means that it can distinguish between variables and functions in the use of upper and lower case letters [19].

\section{RESULTS AND DISCUSSION}

Testing the creation of a Website Application Pasti Makan on the user's authority as a buyer and seller. Buyer transactions in this application can be divided into two, namely direct transactions and customer transactions. In direct transactions, buyers can only schedule on the same day, whereas in subscription transactions, buyers are not limited when scheduling.

\subsection{Preview of Main Menu}

The buyer's main page in Figure 4 is the first main page the buyer encounters shortly after logging in.

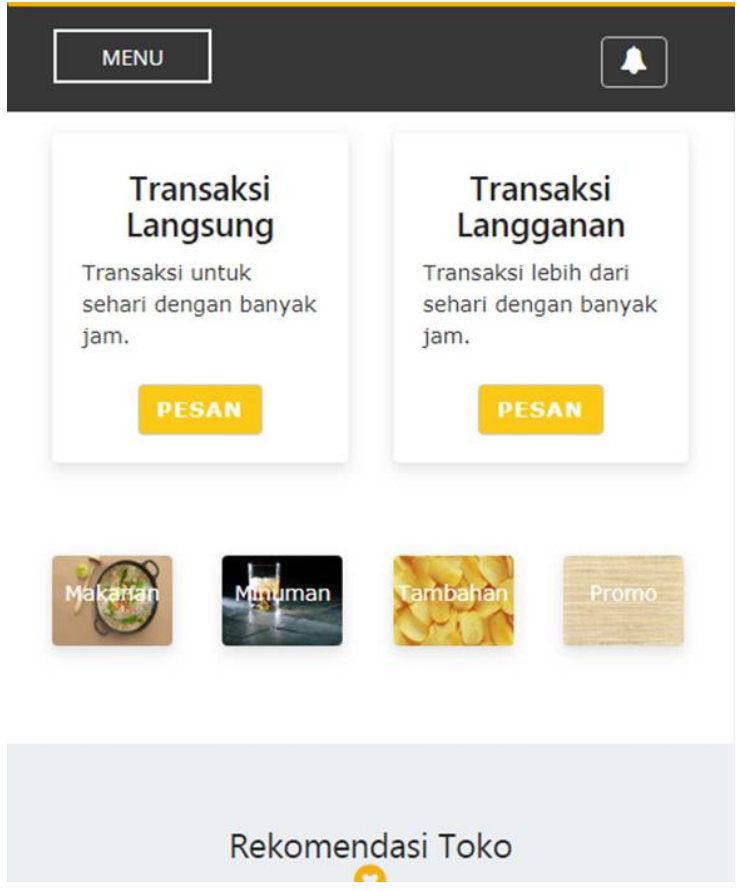

Figure 4. Preview of Main Menu
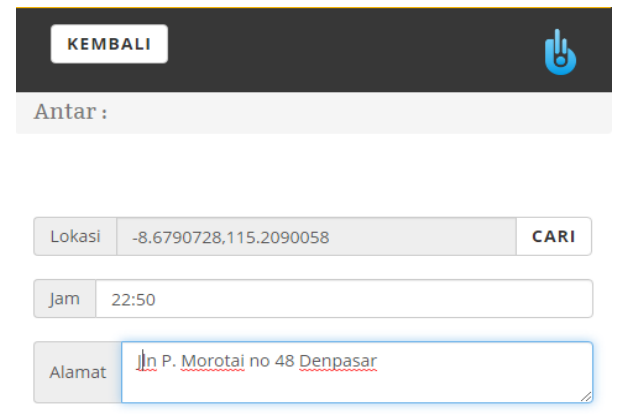

\section{Warung Nasi Bu Oki}

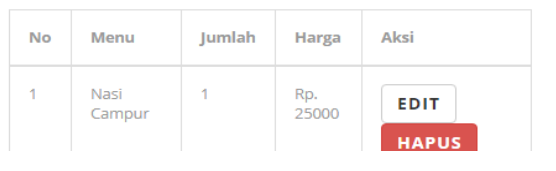

Figure 5. Preview of Direct Transaction's Basket Page

The main menu of Pasti Makan Ordering Application System, contains menu recommendations, store recommendations, categories and direct or subscription transaction buttons.

\subsection{Page of Direct Transaction's Basket}

The direct transaction's basket is a page to view menus ordered by buyers when making direct transactions. The direct transaction's basket page is specifically for buyers who are in the process of purchasing direct transactions. 
The direct transaction basket page in Figure 5 is the page where buyers place orders directly on the system. The buyer selects a store, and then chooses the menu to be ordered along with the amount. The ordered menu is entered on the basket page. This basket page is in the subscription order process and directly to accommodate the ordered menu data. Data needed to conduct transactions is to mark the location of delivery using Google Maps, delivery hours and delivery addresses.

\subsection{Page of Subscription Transaction's Basket}

Page of subscription transaction's basket is a page to see the menu ordered by the buyer when making a subscription transaction. This page is specifically for buyers who are in the process of purchasing a subscription transaction.

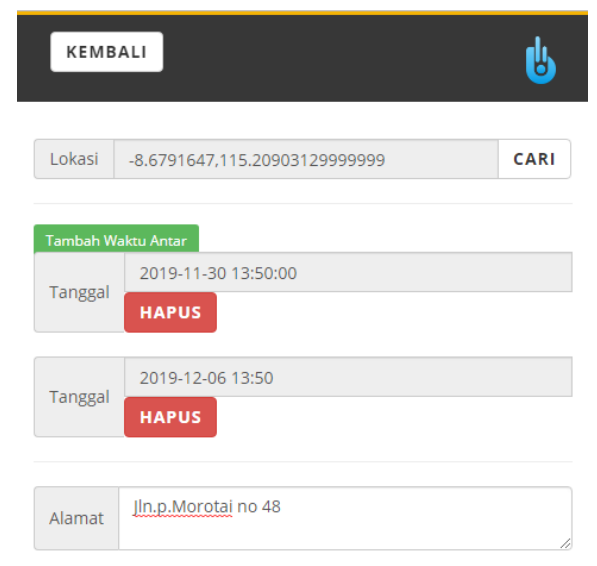

Mc Donald Jimbaran

Figure 6. Preview of Subscription Transaction's Basket Page

Page of subscription transaction's basket in Figure 6 is the page where the buyer places a subscription on the system. The buyer selects a store, then chooses the menu to be ordered along with the amount. The ordered menu is entered on the basket page. This basket page is in the subscription order process and directly to accommodate the ordered menu data. The data required to make a transaction is to mark the location of delivery using Google Maps, the date and time that the subscription order will be delivered.

\subsection{Page of Seller Delivery Schedule}

The inter-seller schedule page is the main page of the seller's user to view the delivery schedules.

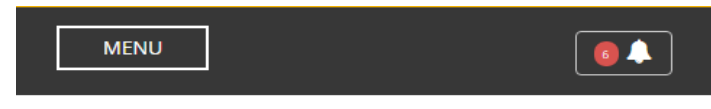

Selamat Datang!

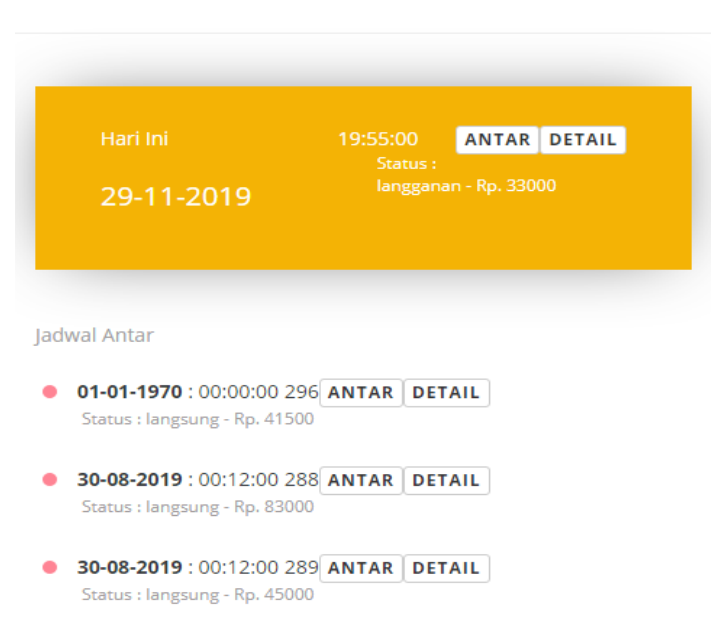

Figure 7. Preview of Seller Delivery Schedule Page

Figure 7 is a preview that presents information about the delivery schedule of orders to be delivered by the seller. Information presented in the form of date, time and total transaction of the order. The information presented is schedule information between today and delivery schedule information for the following days.

\section{CONCLUSION}

The Website Application System of Pasti Makan is produced using cloud computing technology that makes buyers and partners can access the system anywhere and anytime without installing the application. The scheduling system, which is the main feature of this system, can solve the problem of productive people who have little time to get orders by delivering orders on time by providing information in the form of delivery location, delivery date and delivery schedule.

\section{REFERENCES}

[1] Swastika, I. P., Widiatmika, I. M., \& Wiadi, P. E. 2010. Rancang Bangun Sistem Informasi Geografis Penguasaan Pemilikan Penggunaan dan Pemanfaatan Tanah $(\mathrm{P} 4 \mathrm{t})$ Kabupaten Jembrana Berbasis Web. Lontar Komputer, 1(1), 4-16. Darmawan, I. P., Piarsa, I. N., \& Dharmadi, I. P. (2017).

[2] Darmawan, I. P., Piarsa, I. N., \& Dharmadi, I. P. 2017. Ekstrak Hirarki Data dari Situs Web A-Z Animals Menggunakan Web Scraping. Lontar Komputer, 8(3), 166-177.

[3] Nurastryana, K. W. 2003. Implementasi Tabel Federasi dalam Komunikasi Server pada Penjadwalan Seminar Tugas Akhir. Merpati, 1(2), 1-7.

[4] Frediyatma, S. Y. 2014. Aplikasi Pemesanan Makanan Berbasis Cloud dengan Platform Android. Merpati, 2(1), 118-126. 
[5] Khairunnisa, \& Damayanti, F. 2018. Pengolahan Bisnis Catering Ummi Nisa Medan Berbasis Web. Jurnal Sistem Informasi, 2(1), 63-71.

[6] Prawiranata, H., \& Rahmawati, D. 2018. Pengaruh Kualitas Sistem Informasi, Harga dan Kualitas Pelayanan Terhadap Kepuasan Pelanggan Pada Jasa Gojek di Yogyakarta. Jurnal Pendidikan Akutansi, 6(4), 1-22.

[7] Mahardika, I. G. 2014. Aplikasi Back End Manajemen Restoran Berbasis Cloud. Merpati, 2(1), 98-105.

[8] Saputra, P. S., Sukarsa, I. M., \& Bayupati, I. P. 2017. Sistem Informasi Monitoring Perkembangan Anak di Sekolah Taman Kanak - kanak Berbasis Cloud. Lontar Komputer, 8(2), 112-123.

[9] Dharma, I. G., Sukarsa, I. M., \& Sutramiani, N. P. 2019. Rancang Bangun Sistem E-Commerce Marketplace Gypsum Berbasis Cloud Computing. Merpati, 7(1), 3748.

[10] Sudiartha, I. K. 2013. Sistem Informasi Geografis Pura di Pulau Bali Pada Platform Blackberry. Merpati, 1(2), 1-10.

[11] Gautama, I. W., Putra, I. K., \& Sukarsa, I. M. 2016. Aplikasi Pemetaan Objek Wisata Pantai Bali Selatan Berbasis Android. Merpati, 4(1), 43-51.

[12] Utama, F. F., \& Johar, A. 2016. Minuman Restaurant Berbasis Client Server Dengan Platform Android. Jurnal Rekursif, 4, 288-300.

[13] Masruroh, N. 2011. Analisa Penjadwalan Produksi dengan Menggunakan Metode Ampbell Dudeck Smith, Palmer, dan Dannenbring di PT. Loka Refraktoris Surabaya. Tekmapro, 1(1), 158-171.

[14] Pursana, P. E. 2014. Sistem Informasi Koperasi Modul Simpanan Berbasis Android Terintegrasi Berbasis Web. Merpati, 2(1), 67-78.

[15] Putra, M. S., Piarsa, I. N., \& Rusjayanthi, N. K. 2018. Rancang Bangun Sistem Informasi Web-Based Travel Assistant untuk Membantu Perjalanan Wisatawan. Merpati, 6(3), 214-224.

[16] Saputra, I. G., Sasmita, G. M., \& Wiranatha, A. A. 2017. Pengembangan Sistem Keamanan untuk E-Commerce. Merpati, 5(1), 17-28.

[17]Purba, I. R., Purnawan, I. K., \& Sasmita, I. G. 2016. Sistem Antrean Pelayanan Medis Praktik Dokter Bersama Berbasis Web. Merpati, 4(3), 248-258.

[18] Putra, I. M., Piarsa, I. N., \& Mandenni, N. M. 2015. Sistem Informasi Geografis Pemetaan Wilayah Berdasarkan Kualitas Pendidikan di Provinsi Bali. Merpati, 3(3), 108-119.
[19] Harmadya, M., Sasmita, G. M., \& Wirdiani, N. K. 2015. Rancang Bangun Aplikasi Tryout Ujian Nasional Sekolah Menengah Pertama (SMP) Berbasis Android. Lontar Komputer, 6(2), 108-119. 